ル基にとんでいる。

2. VAc 重合でアセトアルデヒドは連鎖移動によって, 高分 子端にケトン型カルボニル基を導入する。

3. クロトンフルデヒド添加 VAc を原料にした PVA に飽和 カルボニル基の吸収を認めた。

4. PVA の熱処理で, 空気や醀酸ナトリウムが化学変化を促 進することを UV 吸収にて認めた。

5. PVA の熱処理で既存カルボニル基は一部ケタール結合を つくる。

6. PVA の窒素系熱処理で, 分子端のカルボニル基に誘起さ
れて脱水, 分裂がおこり, 320 450 $\mathrm{m} \mu$ に吸収を示し, 着色の原 因になる。この吸収は主として PVA とケタールまたはアセター ル結合をしているポリェンカルボニル化合物にもとつくことを推 定した。

7. PVA 中のカルボニル基に隣る $\mathrm{OH}$ 基は塩酸接触で脱水す る。

本研究の発表を許可された会社当局に感謝する。また御指導を いただいた当社小南部長, 浮田博士, 赤外線吸収を測定された西 野豊氏，および紫外線吸収の測定を許可された水野義久教授に深 謝する。

\title{
石炭酸とホルムアルデヒドとの反応における溶媒効果 ${ }^{\dagger}$
}

(昭 和 31 年 1 月 31 日受理)

$$
\text { 間 中” 和 夫* }
$$

\section{I. 緒 霄}

石炭酸とホルムアルデヒドとの反応において，反応液中に混在 するアルコールが反応にどんな影響を及ぼすかについては従来か ら興味が持たれ，それについて報告もされてきた。たとえば柳田 によると1)水のかわりにアルコールを添加するとアンモニア触媒 の場合は反応が遅くなるが，塩酸触媒の場合は反応が速くなると ともに, 反応が通常の 2 次反応にしたがわない異常反応となり， また反応系に水を添加するとアンモニア触媒の場合はその影響が はとんどみられないが，塩酸触媒の場合は反応が遅くなることを 報告している。また上中ら2) は水酸化ナトリウム触媒の場合につ いても報告したが，それによるとアルコールの添加によって反応 が遅くなるとしている。なおアルコールとホルムアルデヒドとの 反応を取报ったるのに香川の報告3) および垣内の報告4)があり， また Megson ら5) は石炭酸とホルムアルデヒドとアルコールと の反応の中間生成物としてアセタールを取出したことを報告して いる。

著者は溶媒効果の機構を明らかにする目的で, 溶媒としてメタ ノール以外にさらにジオキサンをる用い, 触媒として塩酸と水酸 化ナトリウムを用いて実験を行った。メタノールの場合は上記文 献と同様の結果をえたが，ジオキサンの場合は添加量の割合を增 加するにつれて反応速度に極小点の存在することを見出した。こ れらの事柄に対し，理論的な考察をも加えた結果について次に報 告する。

\section{II. 溶媒添加量と速度定数との関保}

A. 央跧方法 石炭酸は試薬 1 級品を再蒸留したもの, ホルマ

†本報告を「石宸酸脂脂の研究（第 6 報）」とする.

*東京艺浦電気株式会社マッダ研究所：川崎市堀川町.

1) 柳田, 科研報告 $24,149,218$ (1948).

2）上中，横山，小林，日化第 8 年会、講演番号 1089 .

3）香川, 熱硬化性樹脂第 1 回討論会講演要旨.

4) 垣内, 同上第 4 回討諭会講演要旨.

5) N. J. L. Megson, A. A. Drummond, J. Soc. Chem. Ind. 49, 251 (1930).
リンは試薬 1 級品を蒸発皿で加熱蒸発してパラホルムにしたるの を蒸留水と煮沸して再びホルマリンにしたものを用いた。メタノ 一ルは試薬 1 級品を再蒸留したもの, ジオキサンは試薬特級品を そのまま用いた。実験条件は第 1 表に示すとおりであって，いま 実験方法を第 1 表の最初の実験 A 1 について説明すると, 37.986

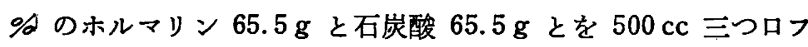
ラスコに入れると,この混合液は $120 \mathrm{cc}$ の容積であるから，これ に溶媒としてジオキサン $80 \mathrm{cc}$ を添加して $200 \mathrm{cc}$ となし, 恒温水 槽中に浸清して反応液が $59^{\circ} \mathrm{C}$ となったときに触媒として 3.927 $\mathrm{N}$-塩酸 $5 \mathrm{cc}$ をピペットにより添加し，このときを反応開始時と

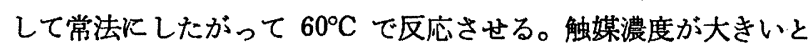
きは反応熱によって反応液の温度が急激に上昇するおそれがある から、このときはあらかじめ用意した水を少量ずつ三つロフラス コに注いで温度を注意深く $60^{\circ} \mathrm{C}$ に保つょうにする。30 分ごと にサンプルを取出して塩酸ヒドロキシルアミン法によりホルムア ルデヒドの定量を行う。

ジオキサンはフェノール類に対しアルコールよりるはるかに盛 溶媒であるため, 乳化に至るまでの時間が短い。この点は実験に 際して注意を要する事柄である。

B. 計算およびその結果 速度定数の算出はホルムアルデヒ ドに関する 2 次式 $\mathrm{d} y / \mathrm{d} t=k(a-y)(b-y)$ によって行った。た だし $a$ は石炭酸の初濃度, bはホルムアルデヒドの初濃度, $y$ は $\boldsymbol{t}$ 時間までのホルムアルデヒドの変化量を表わす。

計算の結果によれば, 速度定数は反応時間とともに增大する場 合もあれば減少する場合もある*1。速度定数を縦軸に，反応時間 を横軸にとってグラフを描けば速度定数曲線がえられる。石炭酸 とホルムアルデヒドとの最初の反応, すなわちメチロール化反応 の速度定数は速度定数曲線を $t \rightarrow 0$ に外挿してえられる。第 1 表 に示した速度定数の值はこうしてえられたメチロール化反応の速 度定数の值である。

速度定数を触媒濃度で除した値，すなわちモル触媒定数は触媒

※1 增大または减少する理由については後報（第 7 報）に扣い て述べる。な打本報告の実験の一部は後報に再録して図示 する。 
第 1 表

(Fnはホルマリン, P は石炭酸, Fd はホルムフルデヒド，Dはジオキサン，W は水，Mはメタノールを第わす)

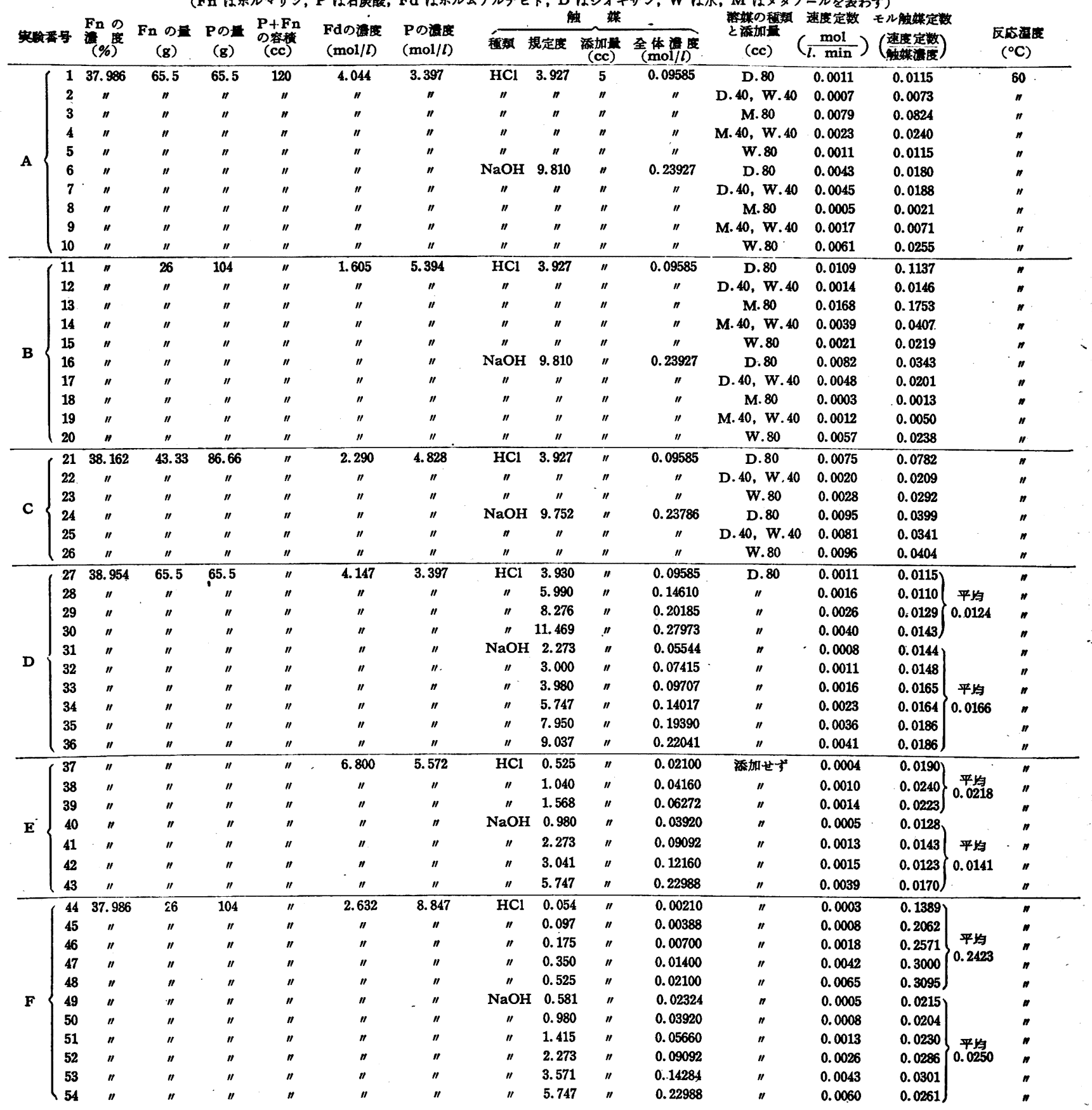

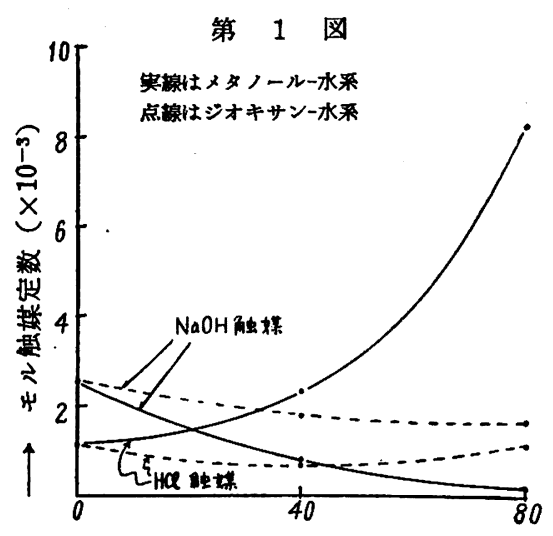

$\longrightarrow$ 溶媒添加量 (cc)

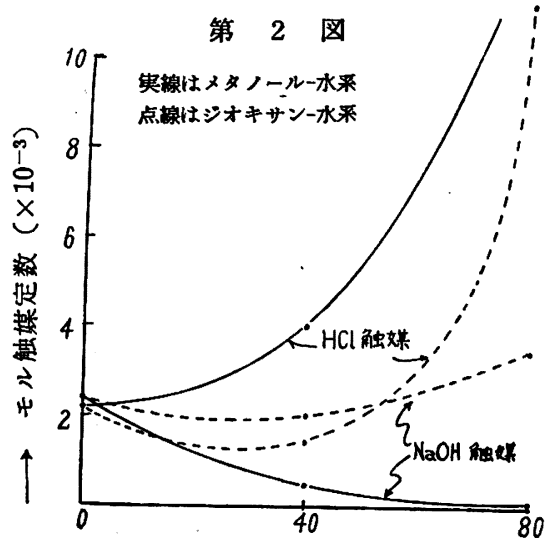

$\longrightarrow$ 溶媒添加量 $(c c)$

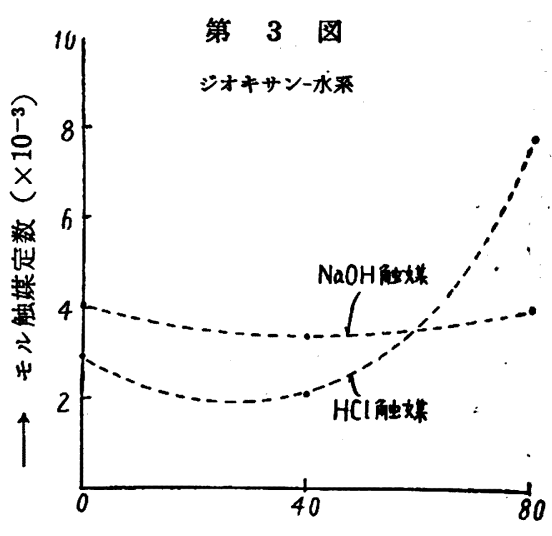

溶媒添加量 (cc) 


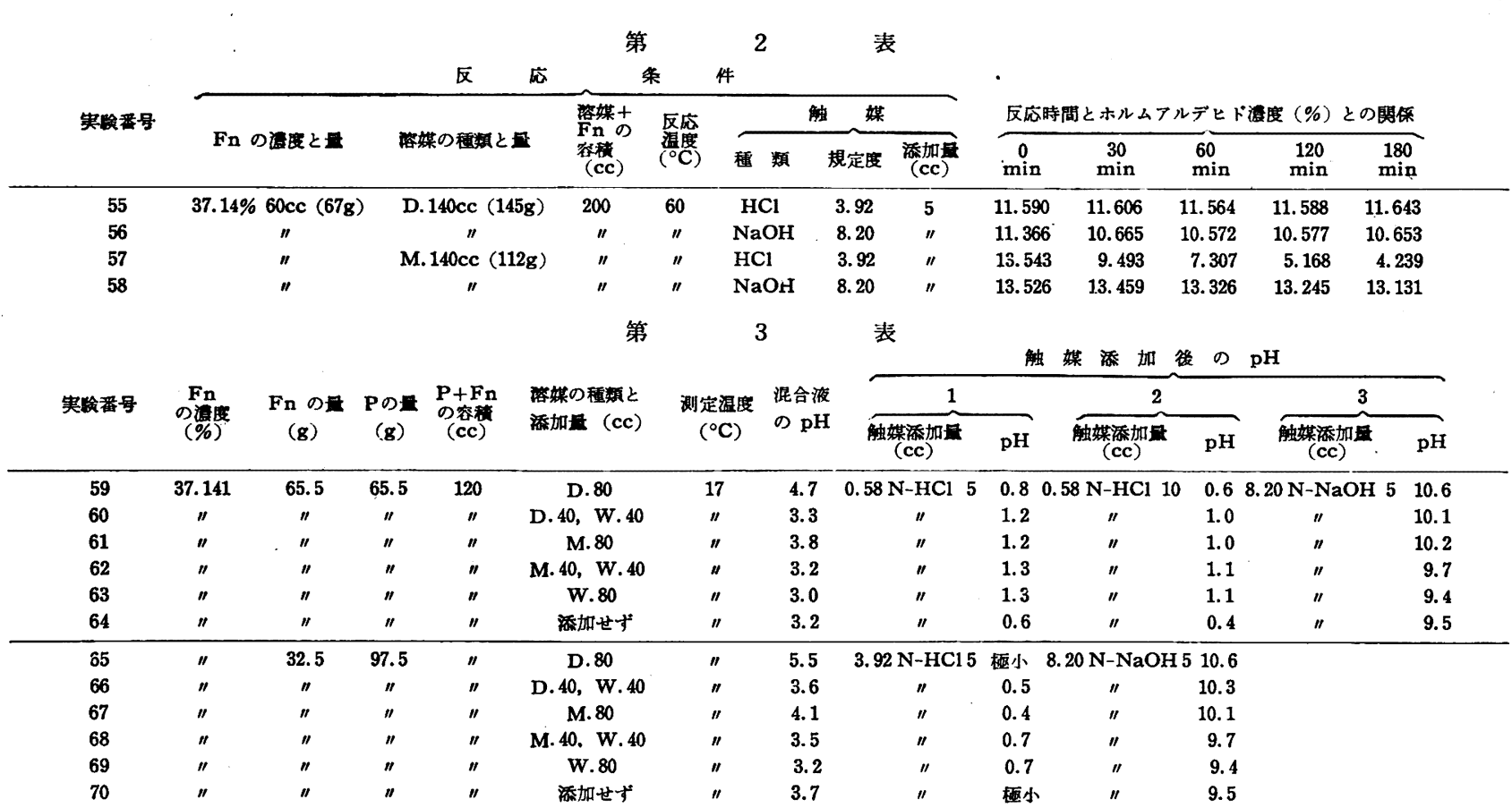

$1 \mathrm{~mol} / l$ 当りの速度定数に相当する。実験 A,B および C につ いてモル触媒定数を縱軸に，溶媒添加量を横軸にとってグラフを 描けば，それぞれ第 1，2 拈よび 3 図がえられる。な敃第 1 表実 験 $\mathrm{D}, \mathrm{E}$ 扎よ゙ $\mathrm{F}$ に执いてモル触媒定数は各実験ごとにほぼ一 定值を示しているが，これは速度定数が触媒濃度にほぼ比例する ことを意味するすのである规, ${ }^{\circ}$ 。

\section{III. 溶媒とホルムアルデヒドとの反応}

ホルムアルデヒドがメタノールまたはジオキサンと，どの程度 反応するものであるか空試験をするために，第 2 表に示すような 反応条件の下で実験を行った。これを実験番号 55 のものについ て説明すれば, $37.141 \%$ のホルマリン $60 \mathrm{cc}$ とジオキサン $140 \mathrm{cc}$ とを三つロフラスコに入れ反応温度 $60^{\circ} \mathrm{C}$ にて $3.92 \mathrm{~N}$-塩酸 5 cc を用いて常法にしたがって反応させ，30 分おきにホルムアル デヒドの濃度を塩酸ヒドロキシルアミン法により滴定するのであ る。

第 4 図

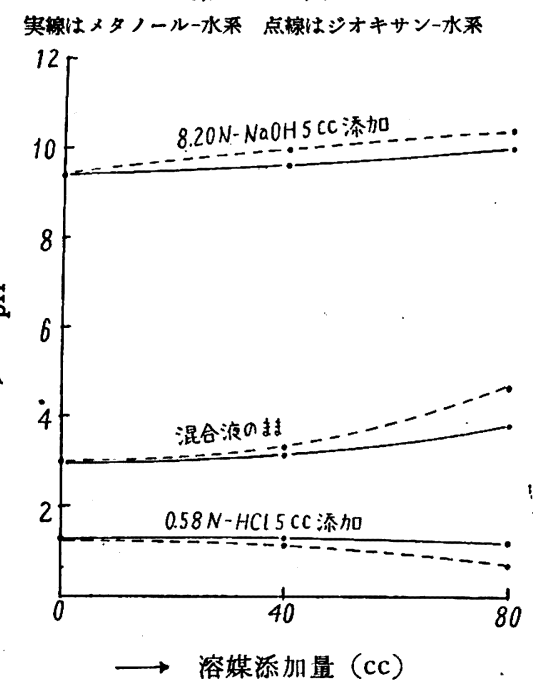

第 2 表によれ ば,この実験条件 ではジオキサンと ホルムアルデヒド は塩酸触媒によっ て反応しないが, メタノールは塩酸 触媒によっていち じるしく反応する ことが明らかで, 本研究ではこの影 響を無視すること は到底できない。 一方水酸化ナトリ ウム触媒の場合は, ジオキサンすメタ
第 5 図

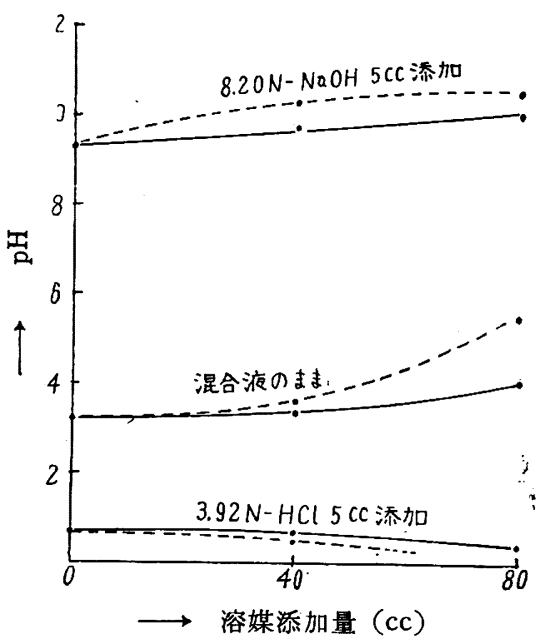

実線はメタノールー水采 点線はジオキサン一水亲

ノールもホルムア ルデヒドとごく僅 か反応するらしく みえるが，これは カニッァロ反応に よる変化と思われ る僅少のむのであ って, 本研究では この程度の変化は 無視することがで きる。

IV. 反応液の
pH

石炭酸とホルマ リンの混合液に溶 媒を添加したときの $\mathrm{pH}$ の值，およびこれにさらに触媒を添加し たときの $\mathrm{pH}$ の值をガラス電極を用いて測定した。測定条件およ び測定結果は第 3 表に示すとおりであるが，いまこれを実験 59 について説明すると，37.141\% のホルマリン $65.5 \mathrm{~g}$ と石炭酸 $65.5 \mathrm{~g}$ とを混合して $120 \mathrm{cc}$ とったものにジオキサン $80 \mathrm{cc}$ を 添加したのち $\mathrm{pH}$ を測定すると $17^{\circ} \mathrm{C} て ゙ ~ 4.7$ となる。この混合液 に $0.58 \mathrm{~N}$-塩酸 $5 \mathrm{cc}$ を添加すると $\mathrm{pH}$ は 0.8 となり, 同じく $10 \mathrm{cc}$ を添加すると 0.6 となる。一方，この混合夜に $8.20 \mathrm{~N}$ 一水 酸化ナトリウム $5 \mathrm{cc}$ を添加すると 10.6 となる。第 3 表の絬果 をグラフに示したものが第 4, 5 図である。

\section{V. 結果の考察}

塩酸触媒の場合, 第 1，2 困によれば，水のかわりにメタノ一 ※2 撖密には速度定数は触媒震度の $n$ 乗に比例するといわれ ている．著者の実験においてもこの候问が見られる。

6) M. M. Sprung, J. Am. Chem. Soc. 63, 334 (1941); 香川, 白井, 工化 54, 66 (1951). 
ルを添加する割合を増大させると反応速度はいちじるしく增大す るが，前述したようにこの反応速度の增大は一部分メタノールと ホルムアルデヒドとが反応するためでもあることを考虑しなけれ ばならない烧3。一方第 1,2 および 3 図によると, ジオキサンの 添加割合を增大させると反応速度はいったん減少するが再び増大 する。すなわちこの場合反応速度に極小点が見られる。

水酸化ナトリウム触媒の場合, 第 $1 ， 2$ 図によればメタノール の添加割合が増大すると反応速度は減少する一方である。また第 1 図によれば, ジオキサンの添加割合が增大すると反応速度は次 第に減少するが, 第 2, 3 図によるとジオキサンの添加割合が増 大すると反応速度はいったん隇少して次に増大し極小点が見られ る。第 1 図の場合はジオキサンに対して水の量が比較的多い場合 であるから，もしジオキサンの添加割合をさらに增大させるとす れば，そのときは極小点が見られるようになると推定されるすの であって，結局ジオキサンの場合は常に極小点が存在するすのと 解釈すべきである。

さて現在の研究段階では, 石炭酸とホルムアルデヒドとの反応 は通常の反応条件の下では, 塩酸触媒の場合は石炭酸分子とメチ ロールイオンとの反応であり, 水酸化ナトリウム触媒の場合は石 炭酸イオンとホルムアルデヒド分子との反応であるとすることに 異論はないと思われる。いまこの反応形式を Hughes および Ingold らの例にならって表にすれば第 4 表のとおりとなる7)。

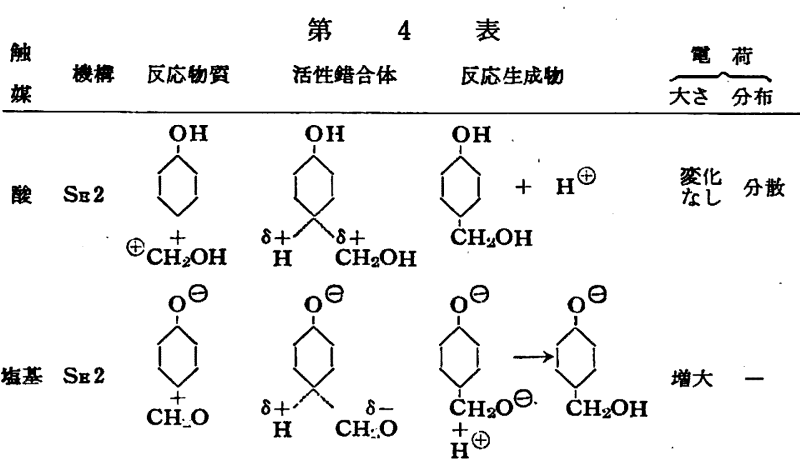

塩酸触媒の場合, ホルムアルデヒドはイオンとして作用するに 対し, 水酸化ナトリウム触媒の場合ホルムアルデヒドは双極子分 子として作用する8)。したがって反応過程において前者の場合， 電荷の分散を伴ない, 後者の場合電荷の増大をきたす。このとき 溶媒として誘電率の大なる水が存在すれば, 前者の場合溶媒和の 減少に基いて反応速度は減少し, 後者の場合溶媒和の增大に基い て反応速度は増大する。換言すれば水よりも誘率電の小さいメ夕

※3 後報（第 8 報）によれば, レッ゙ルシンとホルムアルデヒド を塩酸触媒エタノール中で反応させると，エタノールの添 加割合を增大させても，このよ5な反応速度のいちじるし い增大は見られない。この場合はェタノールとホルムアル デヒドとが反応し難いためである。

7) E. D. Hughes, C. K. Ingold, J. Chem. Soc. 1935, 244; E. D. Hughes, Trans. Faraday Soc. 37, 608 (1941).

8) R. Bieber, G. Trümpler, Helv. Chim. Acta 30, 706, 971, 1109, 1286, 1534, 1860 (1947).

9) F. E. Critchfield, J. A. Gibson, J. L. Hall, J. Am. Chem. Soc. 75, 1991 (1953); G. Åkerlöf, O. A. Short, ibid. 54, 4125 (1932), 58, 1241 (1936).
ノールまたはジオキサンの添加割合が增大すると音, 塩酸触媒の ときは反応速度は增大し, 水酸化ナトリウム触媒のときは反応速 度は堿少することになる。前記した実験事実によると, メタノー ルの場合はこのことを裏書きしている。

ジオキサンの場合, 反応速度に極小点の見られる事実は反応液 の $\mathrm{pH}$ からあ論じられなければならない。Braude らの酸度函数 に関する研究によると年，ジオキサンまたはエタノールに塩酸を 添加する場合. 両者の酸度函数に多少の相違があることが認めら れるが，著者の $\mathrm{pH}$ 測定值においても両者間には明らかに相違が 認められる。すなわち第 4,5図によれば，塩酸を添加する場合，ジ オキサンー水系はメタノールー水系よりる $\mathrm{pH}$ 值の降下が大である に反し, 水酸化ナトリウムを添加する場合ジオキサンー水系はメ タノールー水系よりる $\mathrm{pH}$ 值の上昇が大である。 これらの事実は お゙そらく，塩酸の場合ジオキサンー水系はメタノールー水系よりる メチロールイオンをいっそう少なく生成し，水酸化ナトリウムの 場合ジオキサン一水系はメタノールー水系よりる石炭酸イオンをい っそう多く生成することを示するのではなかろらか。であるとす れば, 塩酸触媒の場合, ジオキサンは誘電率の見地からは反応速 度を增大させる一方であるが，メチロールイオンの生成を小さく する点ではかえって反応速度を減少させ，両者の作用が複合する 結果, 反応速度に極小点が見られるものと解釈できるのである。 同様に水酸化ナトリウム触媒の場合，ジオキサンは誘電率の見地 からは反応速度を減少させる一方であるが，石炭酸イオンの生成 を大にする点ではかえって反応速度を減少させ，その結果極小点 が見られるあのと解釈されるのである。

著者はな後後報において無触媒反応における溶媒効果について も検討し，溶媒効果の機構について重ねて論述したいと思う。

\section{VI. 粉 括}

1. 石炭酸とホルムアルデヒドとを水, メタノール, ジオキサ ンを溶媒とし, 塩酸, 水酸化ナトリウムを触媒として反応させ, メチロール化反応の速度定数を算出した。

2. 水のかわりにメタノールの添加量の割合を多くするにつれ て, 塩酸触媒では速度定数を次第に增大するが, 水酸化ナトリウ ム触媒では次第に減少する。一方ジオキサンでは添加盢の割合を 多くするにつれて, 両触媒の場合とも速度定数を初め減少し, 次 に增大する。

3. 溶媒の添加量の割合により反応液の $\mathrm{pH}$ 值がどう変化する かを測定した。

4. 塩酸触媒のときは石炭酸分子とメチロールイオン, 水酸化 ナトリウム触媒のときは石炭酸イオンとホルムアルデヒド分子と の間に反応が行われるすのとして上記溶媒効果の機構を説明した。

(昭和 30 年 11 月 24 日, 熱硬化性樹脂討論会撑)

終りに本研究について御覞切な御忠言をいたたいた教育大学杉 山塹教授に厚く感謝申上げる。

10) E. A. Braude, J. Chem. Soc. 1948, 1971 1984; A J. Weith, M. E. Hobbs, P. M. Gross, J. Am. Chem. Soc. 70, 805 (1948). 